\title{
Evaluating the Costs and Benefits of Taxing Internet Commerce
}

\section{Citation}

Austan Goolsbee \& Jonathan Zittrain, 52 Nat'l Tax J. 413 (1999).

\section{Published Version}

http://ntj.tax.org/wwtax/ntjrec.nsf/009a9a91c225e83d852567ed006212d8/

d6450204906ce52185256afc007f12b0?OpenDocument

\section{Permanent link}

http://nrs.harvard.edu/urn-3:HUL.InstRepos:9696321

\section{Terms of Use}

This article was downloaded from Harvard University's DASH repository, and is made available under the terms and conditions applicable to Open Access Policy Articles, as set forth at http:// nrs.harvard.edu/urn-3:HUL.InstRepos:dash.current.terms-of-use\#OAP

\section{Share Your Story}

The Harvard community has made this article openly available.

Please share how this access benefits you. Submit a story.

Accessibility 


\title{
EVALUATING THE COSTS AND BENEFITS OF TAXING INTERNET COMMERCE
}

\author{
Austan Goolsbee \\ University of Chicago, G.S.B., \\ American Bar Foundation, and N.B.E.R. \\ Jonathan Zittrain \\ Berkman Center for Internet and Society, \\ Harvard Law School
}

May 20, 1999

\begin{abstract}
Current tax law makes it difficult to enforce sales taxes on most Internet commerce and has generated considerable policy debate. In this paper we analyze the costs and benefits of enforcing such taxes including revenue losses, competition with retail, externalities, distribution, and compliance costs. The results suggest that the costs of not enforcing taxes are quite modest and will remain so for several years. At the same time, compliance costs are likely to be low and the benefits of nurturing the Internet diminishing over time. When tax costs and benefits take this form, a moratorium provides a natural compromise.
\end{abstract}




\section{Introduction}

Existing sales tax law treats goods sold over the Internet the same way it treats goods sold from catalog companies. This means, roughly, that any company without a physical presence in a state (known as nexus) cannot be required to collect that state's sales tax even if the customer lives in the state. If a buyer in Boston, for example, orders a book from amazon.com (located in Washington state), although the buyer technically owes a use tax (equivalent to the sales tax) on the purchase to Massachusetts, the state cannot require amazon.com to collect the tax because amazon has no nexus in Massachusetts. Instead, states must rely on self-reporting and payment by the customers, making enforcement almost non-existent except in special cases such as for goods like automobiles that must be registered. In this sense, the Internet is a virtually tax-free sales channel.

While most of the tax issues raised by the Internet are the same as those raised in the earlier battles over the taxation of mail-order sales (see ACIR, 1986), the rapid growth of online commerce has ignited a major debate as to how Internet commerce should be treated. State Tax Notes has declared the issue of taxes and electronic commerce to be "the hottest topic in multistate taxation." (Sheppard, 1998). On one side, state governments and the National Governors Association have noted the potential revenue losses from online transactions and called for immediate enforcement of sales taxes. On the other, Internet advocates have argued that cyberspace is still fragile and its future uncertain; to tax it now, they say, might seriously damage its growth (see Wyden, 1997; Andal, 1997; Stephenson and Zeisser, 1998). 
In 1998, Congress passed the Internet Tax Freedom Act (ITFA) placing a threeyear moratorium on new taxes on the Internet. The ITFA, however, does not restrict right of States to apply sales and use taxes to online commerce (these are not, after all, new taxes). Instead it primarily prevents states from applying new taxes to Internet access. Its primary effect regarding sales taxes is to prevent states from either applying sales taxes to categories of electronic services or goods with no physical counterpart or applying discriminatory sales taxes on Internet commerce that do not, for example, apply to catalog sales.

Though the ITFA itself did not change the sales tax status quo, it did call for Congress to appoint an advisory commission to come up with recommendations about how the tax system should treat online commerce. The panel's work is taken seriously enough that the National Association of Counties and U.S. Conference of Mayors, fearing that the panel was stacked against local governments, filed suit to prevent the advisory commission created by the ITFA from meeting to draft recommendations.

On the basic issue of weighing the costs and benefits of enforcing taxes on the Internet, most of the discussion has taken place in the political arena rather in academic research (see Graham, 1999; Smith, 1999). Most of the existing academic literature on the subject of Internet taxes has been conceptual discussions and legal analyses. ${ }^{1}$ Because the area is so new there has been very little empirical work. ${ }^{2}$ Most of the explicit discussions weighing the costs and benefits of tax policy toward Internet commerce has taken place in the popular press and has been more political .

In this paper we use the best available data in an attempt to evaluate some of the costs and benefits claimed in the debate about Internet commerce. The lack of systematic 
data sources means that on many important points, the evidence is more qualitative and suggestive rather than definitive. In our discussion, we emphasize the importance of distinguishing between the short and the long run when thinking about Internet commerce. The timing of Internet tax policy is crucial. For example, most of the major benefits from taxing the Internet such as preventing revenue losses or eliminating competition with retail stores and are unlikely to become important for several years while the importance of the costs of taxing Internet commerce including enforcement costs and lost externalities are likely to fall over time. A cost/benefit structure such as this naturally lends itself to a moratorium as a compromise position.

The paper proceeds by evaluating the main costs and benefits of taxing Internet commerce in six sections. These include: revenue loss from Internet commerce, competition with retail trade, distribution, enforcement costs, and externalities. The final section concludes with discussion of the potential for compromise and the future of tax policy.

\section{Revenue Loss from Internet Commerce}

The most important presumed cost of not enforcing taxes on Internet commerce is the potential revenue loss. Sales taxes are, obviously, quite important to state and local government finance. As table 1 shows, in FY 1995-96, general sales taxes raised almost $\$ 170$ billion. This was second only to property taxes as an overall source of tax revenue and was the largest source of revenue for state governments. Give this importance, it is understandable why policy makers are concerned about the issue and decry the potential narrowing of the sales tax base. As the Center for Community Economic Research at 
Berkeley rather colorfully put it, "state and local government finances are becoming road kill on the information superhighway." (Newman, 1995). The National Governors Association has quoted forecasts that by 2002 there may be more than $\$ 300$ billion of commerce over the web or through mail-order and concluded that this will cost up to $\$ 20$ billion in lost tax revenue (Boston Globe, 1998). Similar numbers are often cited by advocates of enforcing Internet taxation (see, for example, Graham, 1999).

As best we can tell, the standard calculation in these revenue loss estimates is made by multiplying total sales by the average tax rate and calling that the loss in revenue. For several reasons, however, this is highly inaccurate. First, the predicted amounts of commerce seem to include business-to-business sales as well as business-to-consumer. The business-to-business is largely exempt from sales tax. Forrester Research, the leading market research company regarding the information economy, has estimated that businessto-business sales will be (and are) much larger than the business-to-consumer (see McQuivey et al., 1998 and Erwin, et al., 1997). Second, the predicted revenue losses ignore the possibility of trade creation. Products that might not have been purchased in a store were it not for the Internet, such as online greeting cards, should not be counted for lost revenue. Third, even if we assume that electronic commerce is entirely diversionary and that all of the commerce will be business-to-consumer, the calculations still have serious flaws by failing to account for the types of products being sold.

Table 2A, for example, presents data from the Boston Consulting Group report on Internet business-to-consumer sales by type of product in the first quarter of 1998 (Boston Consulting Group, 1998). Notice that several of the categories, including financial services, travel, automotive, and, in some states, food and apparel, do not result in lost 
sales tax revenue for the states either because no sales tax applies (travel, financial) or because, although taxable, seller's nexus is likely even if the Internet is used to make purchases (automobiles, groceries). Together, obviously non-taxed categories account for more than $40 \%$ of total online sales in this period (about $\$ 2.3$ billion). ${ }^{3}$

Of the remaining $60 \%$ of sales that may qualify as revenue losers, computer goods alone account for almost half. When calculating the incremental revenue loss from the growth of the Internet, however, computer goods raise several important issues. First, many computer sellers online already pay sales taxes. Having in-state repair services, for example, can create nexus for the seller (see Multistate Tax Commission, 1995) and one of the largest online sellers, Gateway, does charge sales tax.

Second, for those without nexus, it is important to note that not every computer bought over the Internet would have been purchased in a store if the Internet did not exist. Computer goods have had a brisk mail-order business for many years (well before the Internet began). Forrester Research's Technographics data (described in more detail in the appendix) suggests that about $20 \%$ of computer owners purchased their latest machines directly from the manufacturer (while a bit less than $2 \%$ bought them over the Internet). It is doubtful that a customer who today buys from Dell Online, for example, would buy a computer in a store if there were no Internet when she could instead buy from Dell directly by telephone. If Internet sales cannibalize non-taxed catalog sales rather than retail store stales, the growth of Internet commerce does not imply any additional revenue losses to state governments.

Although it is hard to find data to make an industry-wide argument, Dell is an important example. Our estimates indicate that, in the first six months of 1998, Dell may 
have sold around \$435 million online to consumers (more than one quarter of the computer goods in the BCG sample). ${ }^{4}$ Few of those sales were taken away from stores. If not for the Internet, they would have likely gone to Dell's mail-order business.

Taken together, we believe that much of the computer goods category should not be considered a revenue loser. For simplicity, then, let us assume that one half of computer goods sales did not pay the sales tax but would have if the law were changed. The true number is probably much lower. This assumption would imply that another $30 \%$ of online retail sales did not cut into local revenues.

After eliminating all of the non-applicable sales, there were about $\$ 2.5$ billion of sales that may qualify as revenue losses to state governments if we make the somewhat implausible assumption that all auction transactions would have paid sales tax if they had taken place through newspaper classified ads, and so on. The weighted average sales tax rate in the U.S. is about $6.33 \%$ (see Goolsbee, 1998) so the actual revenue loss in the first six months of 1998 was on the order of $\$ 157$ million. Even with a $213 \%$ annual growth rate, the total revenue loss for the 1998 entire year was a bit more that $\$ 430$ million. The same analysis using more detailed data from Forrester Research listed in table $2 \mathrm{~B}$ puts the total revenue loss for 1998 at around $\$ 210$ million (McQuivey, et al., 1998). ${ }^{5}$ With overall sales tax revenue growing at $6 \%$ nominal rates (as indicated in Bureau of the Census, 1997; 1998), the revenue loss in 1998 using either measure amounted to less than onequarter of one percent of total state and local sales tax revenue (or 0.05 percent of total tax revenue).

Looking to the future, Forrester estimates that from now to 2003, online retail spending will grow almost 70 percent per year when it will total more than $\$ 108$ billion. 
Their prediction includes estimates by category. Doing the same calculation on the fiveyears-out projection, yields a revenue loss of $\$ 3.5$ billion-still less than 2 percent of sales tax revenue even after a half-decade of rapid growth. ${ }^{6}$ Doing so suggests that the total revenue loss would be (again assuming only diversionary sales) about $\$ 470$ million in 1999, $\$ 880$ million in 2000, $\$ 1.4$ billion in 2001, $\$ 2.3$ billion in 2002, and $\$ 3.5$ billion in 2003. With average growth rates of general sales taxes, the Internet revenue losses will, even after several years of dramatic growth, amount to less than two percent of sales tax revenue.

To put these revenue numbers in perspective, note that the Census Bureau's Monthly Retail Sales suggests that mail-order sales topped $\$ 55$ billion in 1998 and this is likely to be significantly understated as explained in ACIR (1986). The existence of untaxed catalog sales has not bankrupted state budgets and for the next several years, online sales are likely to be considerably smaller than mail-order sales was even decades ago.

Alternatively, consider the numerical question of how much the sales tax on retail goods would have to rise in order to cover the revenue short-falls generated by the Internet sales. ${ }^{7}$ Based on the Forrester forecasts, to keep revenue constant, the average tax rate on sales would need to rise from $6.33 \%$ to $6.35 \%$ in 1998 . Five years later, in 2003, to keep revenue constant would require an increase from 6.33 percent to about 6.40 percent. These small changes may imply that the costs of enforcement might not be better applied elsewhere in the short run. For example, the estimates in Slemrod (1999) concerning the revenue generated in Michigan from a simple crackdown in cigarette 
smuggling imply that this had a substantially greater impact on Michigan state tax revenue than would aggressive enforcement of Internet taxation.

In some sense, the modest costs of not enforcing taxation on Internet sales numbers illustrate why the advocates immediate enforcement consistently invoke revenue loss projections from well into the future. Only after an extended period of rapid growth will the issue become substantively important. If the growth rate of online retail commerce continues at 70 percent per year after 2003, by 2007, the revenue loss would amount to as much as 10 percent of total sales tax revenue. If Forrester were significantly too conservative and online retail commerce doubled every year, the revenue losses would amount to 10 percent of sales tax revenue as early as 2004 . It is the possibility of these extreme losses, albeit well into the future, that makes the issue of enforcement so politically sensitive today. The states want to ensure that online sales will be taxed before they become important rather than after. When Internet sales account for, say 10 or $20 \%$ of total retail sales, they believe it may be difficult to put the genie back in the bottle. The data suggest, however, that for the next several years, at least, there is little revenue to be gained from enforcing taxes on Internet sales.

\section{Internet Competition With Retail Stores}

Another basic benefit claimed by advocates of enforcing taxes on Internet commerce is to eliminate the unfair disadvantage that uneven tax enforcement puts retail stores at relative to their online (and out-of-state) counterparts. Presumably, there is some notion about tax-induced distortions. If consumers, for example, would prefer to buy from a local store but buy online only to avoid taxes, the tax is creating an inefficiency. ${ }^{8}$ 
Evaluating the competition with retail is really asking whether Internet purchases are being diverted from retail purchases or are wholly new transactions. This is very much like the trade creation versus trade diversion arguments about bilateralism found in the international trade literature (see Viner, 1950). Thus far, Internet sales are so small that no one has addressed the question.

To properly answer it would require panel data on the retail and online buying habits of individuals over time. No such data exist. Instead, we use cross-sectional data from Forrester conducted at the end of 1997, compiled in Technographics '98 and described in the data appendix. This random survey of 110,000 people yielded approximately 25,000 users of the Internet. Each of these individuals was also asked to give a qualitative ranking of how frequently they shop in certain types of retail stores (OFTEN, SOMETIMES, RARELY, NEVER). We aggregate their answers for discount retailers, wholesale clubs, upscale department stores, moderate department stores, and other department stores in two ways. First, we choose the maximum level of shopping in the five categories as the measure of retail shopping (i.e., if they report rarely shopping at an upscale department store and often shopping at a wholesale club, they would count as shopping often). Second, we rank each of the categories numerically ( 0 for never, 1 for rarely, and so on) and sum them across the five store types to get a measure of total retail shopping.

To test for the competition between Internet and retail commerce, we estimate equations for the amount of retail shopping done by an individual controlling for that person's education, income, age, race, gender, marital status, presence of children under 18, use of a computer at work, running of a business from home, and ownership of a 
computer in the year before the survey. In addition to these controls, we also include whether the person has bought online. If online buying comes at the expense of retail buying, we would expect a significant negative coefficient. We do not list the coefficients on the controls for reasons of space but they were generally not surprising.

Because this is not panel data, of course, this regression may suffer from bias due to unobservable, individual-specific traits. This bias could go either way. There could be an upward bias if the people who, beyond their observables, shop online are people with higher consumption levels who shop more in every venue. There could be downward if the people buying online are people who, for example, have little access to retail stores. In either case, the estimated substitution pattern between retail and the Internet will not reflect the true pattern but instead will reflect the distribution of unobservable traits across people. Despite this potential limitations, these are the only data that exist.

Column 1 of table 1 shows the results from an ordered logit estimation where the dependent variable is the maximum amount of shopping (four categories) across the five store types. The results indicate that people who have bought online are more likely to frequently shop at some type of retail store, controlling for individual characteristics. The same is true in column 2 where we conduct an ordered logit of the aggregated measure of shopping (24 categories). There is, again, a small but significantly positive coefficient on buying online for the amount of retail shopping. Finally in column 3 we do a linear regression of the aggregated measure but include state-metropolitan area dummies to account for correlated unobservables, differences in sales tax rates, and so on. The results do not change much. 
Evidence like this is only suggestive, but it does not seem to point to intense competition between retail and online commerce at present-consistent with the notion of Internet as trade creator. As time progresses, however, and the Internet becomes a larger fraction of total retail, the competition may become more intense.

\section{Distributional Considerations}

Not enforcing taxes on the Internet, as argued in the popular press, does have particular distributional effects (see for example, Gillmor, 1999). The incidence is not random. The argument is that online purchasers are disproportionately wealthy so failing to collect tax on Internet commerce then represents an indirect transfer to the rich. If online purchases are not taxed, anyone with enough money to buy a computer can avoid sales tax, while less well-off individuals cannot.

A general lack of data has prevented much analysis of the issue but it seems intuitive that online individuals would be better off than those not online. The Forrester data (listed in Table 4) confirm the significant difference in terms of income and education between wired and non-wired customers. The average Internet user has almost two more years of education and $\$ 22,000$ more family income than the average nonuser.

The regressiveness, however, is becoming noticeably less pronounced over time. Dividing the Internet users up by the year they first started going online, we see that newer users have significantly lower levels of education and income than existing users. Since the number of Internet adopters is accelerating dramatically over time, the data suggest that the distributional issues seem to be lessening over time. 
Furthermore, the data are not consistent with the broader claim that online buying is primarily serving as a way for the rich to avoid paying sales taxes. As the bottom panel of table 3 shows, while richer people are more likely to have online access than poorer people, even among those in the highest third of income (more than $\$ 50,000$ per year), most do not have Internet access. The second column shows, as well, that of those with access, only about one in five has actually bought something online and these rates do not vary much by income level. In addition, the calculations in Goolsbee (1998) and Krantz (1998) suggest that even for those with access who choose to buy, the amount they spend is fairly modest.

\section{Enforcement Costs}

One frequently mentioned potential cost to taxing Internet commerce is the difficulty of enforcing such taxes (see the Economist, 1997). Basic theory suggests that tax rates should be low on activities where enforcement is difficult or costly. The potential enforcement problems of Internet taxes are numerous. First, in a reprise of the original argument establishing the nexus requirement for taxing mail-order business, opponents argue that with more than 6,400 different tax rates in the U.S. (Rappaport, 1994). Simply calculating and remitting the applicable taxes to every jurisdiction from which a customer orders could be quite burdensome, particularly for the smaller, "pushcart" type sellers thought to populate the Internet marketspace. Complex tax regulation enforceable on a mature market might eliminate whole classes of small, less sophisticated Internet sellers. 
Practically speaking, however, this enforcement problem is actually less important than it has been in the past. Calculation of taxes for each particular jurisdiction may be tedious, but such a task is well-suited to an electronic environment. Companies such as Vertex or Taxware International have produced databases that can calculate the amount of tax to be collected if given the address of the purchaser and the amount of the purchase, data known to the merchant for transactions involving the shipment of physical goods. In the unlikely event that private companies price this software beyond the reach of most smaller merchants, state governments would have incentives to invest in a low-cost or even free system fully linked to popular electronic commerce platforms.

Some administrative aspects of remittance still remain. They may entail preregistration with certain state tax authorities and a significant amount of paperwork. Some commentators have suggested the creation of a single national clearinghouse to streamline the ministerial aspects of tallying and remitting tax on transactions made by small firms with customers in multiple jurisdictions (Eads et al., 1997). Here, again, states have a strong incentive to take up simplifying recommendations to make collection easy. Many proposals, for example, would simplify collection by having only a single rate per state. Also, the BCG (1998) report suggests that online sales are actually somewhat concentrated among a small number of sellers. About half of all sales come from the top ten sellers and more than three-quarters come from the top 50. Thus applying a $d e$ minimus rule would probably not result in much reduction in revenue.

A second set of potential enforcement difficulties concern the difficulty of identifying individuals or even transactions in the electronic environment. At the extreme, if both merchant and consumer can be anonymous online (giving no indication of their 
physical location) and can transact in untraceable "e-cash," enforcing the sales tax online could have serious problems.

At present, we do not believe that this difficulty is as relevant as has been portrayed in the popular debate. For now, online commerce is dominated by credit card payments and credit card verification often hinges on whether one can confirm the billing address of the account. Given this zip code and address information, simple software could immediately calculate the tax and send payment for most transactions involving physical goods sold online. Merchants with nexus already make such calculations regularly.

There still remains the potential problem of verifying location of the buyer for transactions involving electronic goods. Note, however, that such transactions are not typically subject to sales tax as they often do not have physical counterparts. This is, then, largely a question of whether sales taxes should apply to this new category of goods. This issue is no different than existing discussions about whether sales taxes should apply to services (see McLure, 1997). Such issues are certainly beyond the scope of this paper and are likely beyond the scope of the ITFA advisory commission, as well.

In the future, however, non-credit card payment mechanisms such as incentivebased scrip-like systems (e.g., "Cybergold,") where members earn and trade "points" redeemable through participating merchants or micropayment systems (e.g., Cybercash and Echarge) may become increasingly important and would seem to restore the problems of anonymous customers. This assumes, however, that the Internet of tomorrow will be similar in the relevant respects to the Internet of today. It is conceivable that compliance and enforcement may actually become easier as the architecture of the Internet evolves to 
better suit electronic commerce-perhaps even easier than they are for non-Internet-based transactions. Further, government policy decisions themselves will likely have a major influence on the "code" underlying the Internet and its transparency to government policy (see Lessig, 1998).

Network effects, for example, are likely to narrow the payment mechanisms down to a small number of choices. So long as there is general centralization at some key point among Internet payment schemes, the government will have a way to collect taxes from most transactions. If policy makers, for example, simply attach their reporting requirements to the most popular payment schemes, they could calculate, collect, and remit sales tax on transactions without requiring the merchant to do much work. An extra charge representing a sales tax would be applied, collected, and electronically remitted as an integral part of each instance of payment. Apart from payment mechanisms, server-side e-commerce software could be revised to incorporate sales tax. Government tax rules would give incentives to (or perhaps even require) those controlling the payment mechanism software to ensure that their products incorporate calculation, collection, and remittance of tax at the moment of sale. Those wanting to evade tax collection and remittance would have to find and use "bootleg," nonstandard software to handle customer payments (and do so in a way that could not be easily detected by state governments).

More generally, the advent of digital signatures to enable trusted commerce means that the respective states can themselves become common to a transaction, freely verifying the residence of someone wishing to buy something. Merchants with consumers who are unable or unwilling to offer residence verification from any jurisdiction could be assessed 
some sort of tax then allocated in a "throwback" way to the jurisdiction in which the merchant operates, or among the known jurisdictions in which the merchant sells (see Eads et al., 1997; Klassen and Shackelford, 1998 analyze the economic effects of throwback rules in the retail context).

The essence of any effort on enforcement is not to spend resources in an effort to eliminate every single instance of fraud. This standard is unrealistic even for retail sales taxes. Rather, the goal is to make compliance easy and evasion difficult so that the problem is limited. In this sense, in the short-run there may be some problems with trying to enforce sales taxes online but looking forward these are unlikely to present a serious problem for standard goods in the electronic environment.

\section{Externalities and Under-Provision}

A final set of cost associated with taxing Internet commerce relate to the potential existence of externalities. According to the results in Goolsbee (1998), if taxes were applied effectively to Internet purchases, there would be a significant reduction in the amount bought online. If there are important externalities, this reduction could be a significant social cost. Many of the arguments in the political arena that we should protect or nurture the Internet at an early stage of development are in this spirit. Here we evaluate two potential sources of social under-provision: network benefits and information problems. $^{9}$

The first is the potential positive externality arising from network externalities-that the benefit to each Internet user rises with the size of the overall network. The idea is that seeding the Internet early will yield large benefits in the future. There is very little 
empirical evidence concerning the magnitudes of network benefits associated with either the Internet in general or Internet commerce specifically. ${ }^{10}$ In the case of online commerce, the potential spillovers may involve local learning spillovers (e.g., a friend explains which websites are useful or that using credit cards online is safe), demand side economies of scale (e.g., with a big enough potential market a merchant will be willing to incur fixed costs to enter various niche markets or develop additional features), or direct network benefits (e.g., if auction sites can create networks of otherwise thin markets, both buyers and sellers benefit). In each case, as the number of Internet customers grows, the value of Internet commerce rises. It is important to note, however, that for network externalities to justify, essentially, infant industry protection of the Internet, electronic commerce must do more than simply divert sales from retail stores as discussed above.

We first ask if there is any empirical evidence favoring the existence of spillovers associated with Internet commerce. Does getting a person to buy online actually lead others to follow suit? Existing data are largely inadequate to answer this question precisely but for the individuals in our data, we have some qualitative information on the topic. In addition to reporting demographics information, people with online access also provide information about the share of their friends and family who buy things online. They can answer ALL (<1\%), MOST (2\%), SOME (17\%), VERY FEW (46\%), or NONE (35\%).

Since this is a single cross-section that lacks further information, we cannot deal with the obvious potential problem of unobserved common traits among friends beyond the observables and location dummies as, for example, Goolsbee and Klenow (1998) do in their study of network benefits. Nor can we show that spillovers are actually externalities 
in the spirit of (Leibowitz and Margolis, 1994). Given that these are the only data available, however, we attempt to examine what correlations exist in them.

We do a standard probit regression of whether an individual with online access has bought something online. In it, we include the same individual control variables as before (income, age, education, race, marital status, the presence of children, the use of a computer at work, the operation of a business from home, whether the individual already had a computer in the year preceding the survey, and dummy variables for the metropolitan area of residence). In addition, we include dummy variables for the share of friends buying online. If there are local spillovers, having more friends and family buying online should make the individual more likely to purchase. As shown in table 5, people are more likely to have bought on the Internet the greater the share of their friends that have done so. Moving from having no friends buying online to having most buying online, for example, raises the probability of purchase by more than 0.40 . This is a large and significant coefficient and is consistent with local spillovers (although also consistent with common unobservables among friends).

At the same time, it is important to think about the size of future network externalities. The major network externalities are likely to exhausted or at least diminished once the Internet achieves major scale. Too often, arguments for infant industry protection transform into arguments established industry protection arguments though completely lacking in merit. Further, we expect that eventually there will be an important negative network externality at work (to the extent it is not already) in increasing Internet congestion due to the prevalence of zero marginal cost pricing. ${ }^{11}$ The 
congestion problem is likely to get worse as the Internet grows and argues against subsidizing the growth rate through tax policies.

The second externality-type argument regards the information problems associated with the security of Internet transactions. In reality, credit card security on the Internet is extremely high. There are no direct calculations of the incidence of online fraud but experts generally agree that it is much more likely to have one's credit card number stolen over the phone, for example, than online yet over-the-phone use is common (Fraza, 1998). Further, even if one's credit card is stolen, there is a $\$ 50$ limit on the amount that the consumer is liable for the charges.

The Forrester Technographics 98 data asked the $80 \%$ of Internet users who have not bought online why they have not done so. By far the most common answer, accounting for $45 \%$ of the responses, was that they did not want to give out their credit card information over the Internet. When asked to give their opinions of the level of security of credit card information given out over the web (rated from one to ten with ten being extremely secure and one being not at all secure) the respondents' average rating was only a 2.9. The overall safety and the limited risk associated with Internet purchases does not appear to be widely understood by Internet users.

With the apparent asymmetric information on the part of new consumers about security, there may be justification for encouraging people to try shopping online. In the social sense, there may be too little Internet commerce. Qualitatively, this is a cost of taxing Internet commerce, though, again, this is a strictly short-run justification. Once Internet commerce is established as a conventional sales channel, there is no reason to give a benefit. 


\section{Conclusion}

In this paper we have examined the costs and benefits associated with enforcing taxes on Internet commerce. The results suggest several things. One, because of its limited size relative to retail and because of the type of products being purchased, aggressive enforcement of taxes on Internet commerce would raise only a small amount of revenue over the next several years. Two, Internet commerce does not seem to be primarily fueled by diversion from retail sales. Third, not enforcing taxes on the Internet does disproportionally benefit higher income and high educated people but this effect has lessened substantially in the last two years. Fourth, the costs of complying with taxes on Internet commerce are unlikely to be very large for most online transactions. Fifth, there is suggestive evidence of spillovers and of information problems that should be considered costs of aggressively applying taxes. These benefits are primarily restricted to the short run, however.

Given that the costs of maintaining the status quo are small and the benefits of nurturing the Internet seem to be somewhat concentrated in the short run, a natural compromise position might be a moratorium on enforcement of Internet sales taxes in the short-run followed by equal treatment once the conditions change. This is not quite the same as the Internet Tax Freedom Act of 1998. The ITFA is a moratorium only on new and discriminatory taxes and leaves the broader question of sales taxes to be resolved in the future upon the recommendations of an Advisory commission. Hopefully, results such those in this paper will encourage advocates and policy makers on both sides to give more empirical thought to the tax issues raised by the Internet. 

TABLE 1:

TOTAL STATE AND LOCAL TAX REVENUE IN THE U.S. (in millions of \$)

\begin{tabular}{|cccc|}
\hline Type Of Revenue & $\begin{array}{c}1995-96(\mathrm{FY}) \\
\text { State and Local }\end{array}$ & $\begin{array}{c}1995-96(\mathrm{FY}) \\
\text { State }\end{array}$ & $\begin{array}{c}1995-96(\mathrm{FY}) \\
\text { Local }\end{array}$ \\
Total Tax Revenue & 689,038 & 418,390 & 270,602 \\
& & & 29,709 \\
General Sales Taxes & 169,071 & 139,363 & 199,467 \\
& & & 13,296 \\
Property Taxes & 209,440 & 9,973 & 2,693 \\
Individual Income Taxes & 146,843 & 133,548 & 13,123 \\
Corporate Income Taxes & 32,009 & 29,315 & 12,313 \\
Selective Sales Taxes (Total) & 79,922 & 66,751 & \\
Other Taxes and Charges (Total) & 51,753 & 39,440 & \\
& & & \\
& & & \\
\end{tabular}

Source: Bureau of the Census, United States State and Local Government Finances 
TABLE 2A:

ESTIMATED ONLINE CONSUMER SALES BY SECTOR (FIRST 6 MONTHS OF 1998)

\begin{tabular}{|cc|}
\hline Sector & Amount (in millions of \$) \\
Computer Goods & 1,510 \\
Financial Services & 1,429 \\
Auctions & 898 \\
Travel & 848 \\
Books and Entertainment & 366 \\
Gifts & 138 \\
Consumer Goods & 138 \\
Apparel & 92 \\
Food and Wine & 67 \\
Automotive & 28 \\
Home and Garden & 27 \\
Total & 5,541 \\
\hline
\end{tabular}

Source: Boston Consulting Group (1998). 
TABLE 2B: ONLINE REVENUE BY CATEGORY IN 1998 AND 2003 (\$million)

\begin{tabular}{|ccc|}
\hline Category & Estimate: 1998 & Forecast: 2003 \\
\hline Total U.S. Revenue & 7,826 & 108,031 \\
Software & 665 & 3,179 \\
Books & 630 & 3,002 \\
Music & 187 & 2,495 \\
Videos & 151 & 1,346 \\
Event Tickets & 115 & 2,572 \\
Apparel & 530 & 13,510 \\
Flowers & 212 & 11,699 \\
Greetings & 36 & 320 \\
Specialty Gifts & 63 & 544 \\
Toys & 68 & 1,481 \\
Sporting Goods & 56 & 1,918 \\
Tools and Garden & 63 & 1,021 \\
Travel & 3,073 & 29,447 \\
Computer Hardware & 1,090 & 14,965 \\
Consumer Electronics & 84 & 6,132 \\
Appliances & & \\
Household Goods & 17 & 2,275 \\
Food \& Beverage & 83 & 3,446 \\
Health and Beauty & 235 & 10,836 \\
Misc. & 213 & 6,294 \\
\hline
\end{tabular}

Source: Forrester Research, inc. 
TABLE 3:

IMPACT OF ONLINE BUYING ON RETAIL SHOPPING FREQUENCY

\begin{tabular}{|cccc|}
\hline & $(1)$ & $(2)$ & $(3)$ \\
Bought Online & .153 & .183 & .248 \\
& $(.034)$ & $(.029)$ & $(.039)$ \\
Other Controls & 11 variables & 11 variables & 11 variables \\
Dummies & None & None & Metro-State \\
& & & \\
Estimation & Ordered logit & Ordered logit & OLS \\
$\mathrm{n}$ & 24,412 & 22,465 & 22,465 \\
$\mathrm{R} 2$ & -- & -- & .08 \\
\hline
\end{tabular}

Notes: The dependent variable in (1) is the maximum amount of shopping reported in the five categories as described in the text. The dependent variable in (2) and (3) is the summation of the five categories, also as described in the text. Standard errors are in parentheses. The included control variables are not listed for space. They are the same variables as those in table 5. The estimation method is listed at the bottom of the column. 
TABLE 4:

INCOME AND EDUCATION OF INTERNET USERS

\begin{tabular}{|ccc|}
\hline & Income & Education \\
Internet Access & 57.2 & 14.9 \\
No Internet Access & 35.6 & 13.0 \\
& & 15.6 \\
Internet 3+ years & 61.4 & 15.2 \\
Internet 2-3 years & 61.4 & 14.8 \\
Internet 1-2 Years & 58.4 & 14.3 \\
Internet $<1$ year & 52.2 & Share of Online Users Having \\
& & Bought Online \\
& Share Online & .17 \\
Income $<25,000$ & .11 & .21 \\
Income 25-50,000 & .22 & .23 \\
Income $>50,000$ & .41 & \\
\hline
\end{tabular}

Source: Author's calculations using data from Forrester Research, Inc. 
TABLE 5:

INFLUENCE OF FRIENDS ON THE PROBABILITY OF BUYING ONLINE

\begin{tabular}{|cc|}
\hline Variable & $(1)$ \\
ALL FRIENDS BUY ONLINE & $.470(.049)$ \\
MOST FRIENDS BUY ONLINE & $.408(.021)$ \\
SOME FRIENDS BUY ONLINE & $.333(.007)$ \\
VERY FEW FRIENDS BUY ONLINE & $.147(.006)$ \\
INCOME & $.003(.001)$ \\
EDUCATION & $.005(.001)$ \\
AGE & $-.002(.001)$ \\
FEMALE & $.061(.005)$ \\
SINGLE & $.025(.006)$ \\
CHILDREN UNDER 18 & $-.041(.006)$ \\
ASIAN & $-.011(.018)$ \\
NON-WHITE MINORITY & $-.009(.007)$ \\
USE A COMPUTER AT WORK & $.005(.006)$ \\
RUN A BUSINESS FROM HOME & $.044(.007)$ \\
OWNED A COMPUTER IN 1996 & $.110(.007)$ \\
Dummies & \\
N & Metropolitan Area \\
R2 & 24059 \\
& .14 \\
\hline
\end{tabular}

Notes: The dependent variable is a variable equal to one if the respondent reports having bought something online in the past three months. Standard errors are in parentheses. The equation is estimated using a Probit. 


\section{BIBLIOGRAPHY}

Advisory Council on Intergovernmental Relations, State and Local Taxation of Out-ofState Mail Order Sales, Government Printing Office, 1986, Washington, D.C.

Andal, Dean F., "State and Local Taxation of Electronic Commerce: Read my E-mail, No New Taxes," presented at the symposium on Multi-Jurisdictional Taxation of Electronic Commerce, Harvard Law School, Cambridge, Mass., April 5, 1997, State Tax Notes, Vol. 12, No. 18 (May 5, 1997), pp. 1387-95.

Bohm, Roger, Hans-Werner Braun, Kimberly Claffy, and Stephen Wolff, "Mitigating the Coming Internet Crunch: Multiple Service Levels Via Precedence,” Mimeo, 1995, U.C.S.D.

Boston Globe, “Governors Fear Tax Loss From Internet,” December 31, 1998.

Bureau of the Census, Monthly Retail Sales, Various Issues, Government Printing Office, Washington, D.C.

Cortlett, W. and D. Hague, "Complentarity and the Excess Burden of Taxation," Review of Economic Studies, 1954, 21: 21-30.

Eads, James; Duncan, Harley; Hellerstein, Walter; Ireland, Andrea; Mines, Paul; and Reid, Bruce, National Tax Association Communications and Electronic Commerce Tax Project Report No. 1 of the Drafting Committee, 1997, State Tax Notes 1255, Doc 97-30985.

Erwin, Blane, Mary Modahl, and Jesse Johnson, "Sizing Intercompany Commerce," The Forrester Report, July 1997, 1(1).

Dell Corporation, Fact Sheet, 1998 Q1, <http://www.dell.com/corporate/investor/ factsheet/factsheetQ1fy98.htm>, access date May 2, 1999.

Department of Commerce, The Emerging Digital Economy. G.P.O., 1998; Washington, D.C..

Economist, The, “Taxes Slip Through the Net,” p. 22, May 31st, 1997.

Fox, William and Matthew Murray, “The Sales Tax and Electronic Commerce: So What's New?" National Tax Journal, 1997, 50(3), 573-592.

Fraza, Victoria, “As Internet Purchasing Increases, Security Concerns Take Center Stage for Buyers and Sellers,” Industrial Distribution, December 31, 1998.

Goolsbee, Austan, "In a World Without Borders: The Impact of Taxes on Internet Commerce," NBER Working Paper \#6863, 1998. 
Goolsbee, Austan and Peter Klenow, "Evidence on Learning and Network Externalities in the Diffusion of Home Computers," Mimeo, University of Chicago, GSB, 1998.

Graham, Senator Robert, "Should the Internet Be Taxed? Communities Hurt if the Web Isn't Taxed," Roll Call, February 22, 1999.

Gupta, Alok, Dale Stahl, and Andrew Whinston, “The Internet: A Future Tragedy of the Commons?" Mimeo, 1995, University of Texas.

Hellerstein, Walter, "Telecommunications and Electronic Commerce: Overview and Appraisal," State Tax Notes, 1997a, Vol. 12, No. 7, pp. 519-26.

Hellerstein, Walter, "Transactions Taxes and Electronic commerce: Designing State Taxes that Work in an Interstate Environment," National Tax Journal, 1997b, Vol. 50, No. 3, pp. 593-606.

Hellerstein, Walter, "State Taxation of Electronic Commerce: Preliminary Thoughts on Model Uniform Legislation," presented at the symposium on MultiJurisdictional Taxation of Electronic Commerce, Harvard Law School, Cambridge, Mass., April 5, 1997c, State Tax Notes, Vol. 12, No. 17, pp. 1315-24.

Horner, Frances, and Jeffrey Owens, "Tax and the Web: New Technology, Old Problems," International Bureau of Fiscal Documentation Bulletin, Nov/Dec 1996, 516523.

Klassen, Kenneth, and Douglas Shackelford, "State and Provincial Corporate Tax Planning: Income Shifting and Sales Apportionment Factor Management" 1998, Journal of Accounting and Economics

Krantz, Michael, “Click Till You Drop,” Time, July 20, 1998.

Leibowitz, S. and Stephen Margolis, "Network Externality: An Uncommon Tragedy," Journal of Economic Perspectives; 8(2), 1994, pp. 133-50.

Lessig, Lawrence, The Laws of Cyberspace, Mimeo, 1998 <http://cyber.law.harvard.edu/ works/lessig/laws_cyberspace.pdf $>$, access date May 2, 1999.

Mackie-Mason and Varian, "Some Economics of the Internet," in Networks, Infrastructure and the New Task for Regulation, W. Sichel, ed. Ann Arbor: University of Michigan Press, 1996.

Mackie-Mason and Varian, "Pricing the Internet," in Public Access to the Internet, Brian Kahin and James Keller, eds. Cambridge, MA: MIT Press, 1995: 269-314. 
McQuivey, James, Kate Delhagen, Kip Levin, and Maria LaTour Kadison, "Retail's Growth Spiral," The Forrester Report, November 1998, 1(8).

McLure, Charles (forthcoming), "Taxation Of Electronic Commerce: Economic Objectives, Technological Constraints, and Tax Law," National Tax Review.

McLure, Charles, “Achieving a Level Playing Field for Electronic Commerce:

Policy Considerations," 1998, State Tax Notes

McLure, Charles, "Electronic Commerce, State Sales Taxation, and Intergovernmental Fiscal Relations," National Tax Journal, 1997, 50(4), 731-750.

Multistate Tax Commission, "Computer Company's Provision of in-state Repair Services Creates Nexus,” 1995, Nexus Program Bulletin NB 95-1

Murray, Matthew, "Telecomunications Services and Electronic Commerce: Will Technology Break the Back of the Sales Tax?" State Tax Notes, 1997, pp. 273-80.

Newman, Nathan, "Prop 13 Meets the Internet: How State and Local Government Finances are Becoming Road Kill on the Information Superhighway," Mimeo, 1995, Center for Community Economic Research, University of California, Berkeley.

Rappaport, Neal, Applied Econometric Essays on Sales Taxes and Computer Price Indices, Ph.D. Dissertation, M.I.T, 1994.

Sandmo, A., "Income Tax Evasion, Labour Supply, and the Equity-Efficiency Tradeoff," Journal of Public Economics, 16(3) December 1981, pp. 265-88.

Sheppard, Doug, "Representatives Of Cities, Software Publishers Square Off On Internet Taxation." State Tax Notes, 1998, 15 (941).

Sheppard, Lee A., "What Does 'No New Internet Taxes' Mean?" Tax Notes, Vol. 76, No. 3 (July 21, 1997a), pp. 309-16.

Slemrod, Joel,"Estimating System-Dependent Tax Elasticities: The Case of the Michigan Cigarette Tax Increase“ Mimeo 1999, University of Michigan.

Smith, Senator Robert, "American Consumers Can't Afford Another Tax" Roll Call, February 22, 1999.

Steele, Thomas H. and Walter Hellerstein, "State and Local Taxation of the Information Highway," National Tax Association, Proceedings of the 86th Annual Conference, 1994, Charleston, South Carolina, pp. 221-25. 
Stephenson, Jack, and Michael Zeisser, "Don't Tax the Internet--Yet," Wall Street Journal, June 6, 1998.

Trandel, Gregory, "Evading the Use of Tax on Cross-Border Sales: Pricing and Welfare Effects," Journal of Public Economics, 1992, 35, 333-354.

Wyden, Ron, Statement on the Internet Tax Freedom Act. Homepage of the United States Senate, 1997, <http://www.senate.gov/ wyden/leg/cybstate.htm>, access date, November 10, 1998. 


\section{DATA APPENDIX}

Forrester Research is a leading market research company whose specialty is the information economy. In their Technographics 98 program they conducted a major consumer survey about technology in which they asked more than 110,000 people about their characteristics and their ownership of technology (the field work was done by the NPD Group). More description of the survey can be found in Goolsbee (1998).

The individual variables we use are income, education, age, gender, marital status, race, children under 18, ownership of a computer in 1996, use of a computer at work, and running of a business from home. We turned the series of dummy variables for education, age, and income into continuous variables. If income was stated as between 35 and 40 thousand dollars, for example, we imputed an income of 37.5 thousand. For top-coded variables, we tried various values but changing them had almost no impact on the results. Similarly, just including the variables as dummies gave the same results, as well.

Though the sampling methodology is proprietary, it is meant to make the survey nationally representative and is both widely respected and very expensive for private sector companies. It also matches up somewhat well with government sources such as the Current Population Survey on obvious variables like income, gender, and so on.

The survey also presents data about whether individuals owned a computer, when they got their computer, what type of computer, whether they had access to the Internet, and many other questions of this nature. For those who reported having online access, they were also asked how long they had been online, whether they had bought something online, what share of their friends and family are online, and what share of their friends and family have bought something online. These are variables we use in our analysis. 


\section{ENDNOTES}

We wish to thank the American Bar Foundation and the Berkman Center for Internet and Society for financial assistance and Ben Edelman, Christine Jolls, Peter Klenow, Lawrence Lessig, and Steven Levitt for helpful comments. Michelle Spaulding and David Melaugh provided excellent research assistance on the project.

\footnotetext{
${ }^{1}$ Examples of the existing literature include Fox and Murray (1997), Hellerstein (1997a; 1997b; 1997c), Horner and Owen (1996), McLure (1997; 1998; forthcoming), Murray (1997), and Steele and Hellerstein (1994).
}

${ }^{2}$ One exception is Goolsbee (1998) who empirically examines the question of how current sales tax rates influence the likelihood of consumers to buy over the Internet.

${ }^{3}$ In this calculation we ignore the fact that in some states food and clothing are exempt from sales tax. This would make the number even larger.

${ }^{4}$ This estimate is calculated as follows: At the end of 1998/start of 1999, Dell announced online sales at a rate of $\$ 14$ million per day or $\$ 1.25$ billion per quarter (Dell, 1999). Since this is after a substantial growth rate over the course of the year we assume that Dell's revenue over the year grew at the 213 percent annual rate (33 percent per quarter) estimated in the BCG (1998) report for total commerce that Dell's online sales were divided the same way as their total sales (according to Dell, 1998, this was about 65\% to government, big business, and educational users). With total sales of $\$ 1.25$ billion in the last quarter of 1998 , this would imply sales of $\$ 531$ million and $\$ 707$ million in the first two quarters of the year and if $35 \%$ of these sales were to individuals, this would total $\$ 435$ million for the period.

${ }^{5}$ This assumes one half of computer software and computer hardware currently do not pay sales taxes but would under a rule change. It also assumes that flowers and food satisfy the nexus requirements and thus do not result in revenue losses when purchased online. Event tickets and online greetings are assumed to be untaxed.

${ }^{6}$ Repeating the analysis in the interim years yielded a revenue loss of $\$ 470$ million in 1999 , $\$ 880$ million in 2000, $\$ 1.4$ billion in 2001, and $\$ 2.3$ billion in 2002. The last number is 15 to 20 times smaller than the estimates quoted by advocates in the popular press for the same year.

${ }^{7}$ This is assuming no behavioral responses on the part of retail sales of raising the sales tax by very small amounts.

${ }^{8}$ Note that optimal tax theory does not necessarily call for the rates to be equal on the two types of commerce. While the well-known results of Cortlett and Hague (1954) suggest that we should tax similar goods similarly, if the price elasticities of Internet customers and retail customers are very different it may actually be efficient to allow those with high elasticities to have lower rates. This is the finding of Sandmo (1981) in a different context. In some sense, the least distortive tax would be the one with high rates on those people who would not change their behavior. Given the high implied price elasticities of 
electronic commerce found in Goolsbee (1998), the Sandmo result might suggest that, fairness considerations aside, rates should be lower for Internet commerce.

${ }^{9}$ There is a third potential externality relating to retail market power but we do not consider it in detail here. If local retailers have market power, Trandel (1992) shows that having a tax-free outside option can reduce this market power and actually improve consumer welfare. Given that we have no data on market power, we will just assume that markets are competitive.

${ }^{10}$ Goolsbee and Klenow (1998) show that there seem to be significant local spillovers from using the Internet and using e-mail.

${ }^{11}$ Some important early discussions of congestion can be found in Mackie-Mason and Varian (1995; 1996), Bohm et al. (1994), and Gupta et al. (1995). 